\title{
Journal of Applied Veterinary Science and Technology
}

\author{
www.e-journal.unair.ac.id/index.php/JAVEST
}

\section{The Potency of Giving Turmeric (Curcuma domestica Val) Flour to The Quality of Quail (Coturnix coturnix japonica) Eggs}

Potensi Pemberian Tepung Ampas Kunyit (Curcuma domestica Val) Terhadap Kualitas Telur Puyuh (Coturnix coturnix japonica)

\author{
Astrid Annisya Adhy Putri ${ }^{*}$, Agus Widodo², Ratna Damayanti ${ }^{3}$, Tri Wahyu Suprayogi ${ }^{2,4}$ \\ ${ }^{1}$ Student of Veterinary Paramedic Study Program, Faculty of Vocational Studies, Universitas Airlangga, Surabaya-Indonesia \\ ${ }^{2}$ Department of Health, Faculty of Vocational Studies, Universitas Airlangga, Surabaya-Indonesia \\ ${ }^{3}$ Department of Basic Veterinary Medicine, Faculty of Veterinary Medicine, Universitas Airlangga, Surabaya-Indonesia \\ ${ }^{4}$ Department of Veterinary Reproduction, Faculty of Veterinary Medicine, Universitas Airlangga, Surabaya-Indonesia
}

\section{A B S T R A C T}

\begin{abstract}
Background: Supplementation of good feed on quail can improve its egg quality. One of the excellent supplement comes from herbs. Turmeric is one of the herbs which good for livestock because of its content, curcuminoid, and essential oil. Curcuminoid can increase quail egg yolk color, increase the appetite so that it can increase the weight of poultry. Purpose: To know the potential of giving turmeric flour to the quality of quail's egg. Methods: The methods used 40 quails, divide into two groups. Groups PO: quail fed without turmeric flour, and group P1: quails fed with 1,07\% turmeric fluor. Variables observed were egg weight, haugh unit, egg yolk index, white egg index, and yolk color. Result: The Egg weight, haugh unit, yolk index, and yolk color of P1 was higher than quails fed without turmeric. However, there was no difference between the egg whites index of both groups. Conclusion: The addition of turmeric on feed has the potential to increase the egg weight, haugh unit, yolk index, and yolk color. However, turmeric was not directly affected the formation of egg whites.
\end{abstract}

\section{A B S T R A K}

Latar Belakang: Pemberian pakan tambahan yang baik pada burung puyuh dapat meningkatkan kualitas telur puyuh. Salah satu pakan tambahan yang baik yaitu berasal dari tanaman herbal. Kunyit merupakan salah satu tanaman herbal yang baik bagi ternak karena memiliki kandungan kurkuminoid yang dapat meningkatkan warna kuning telur dan menambah nafsu makan sehingga dapat menambah bobot unggas. Tujuan: Untuk mengetahui potensi pemberian tepung ampas kunyit terhadap kualitas telur puyuh. Metode: Menggunakan 40 ekor puyuh petelur yang dibagi menjadi dua kelompok. Kelompok PO: dengan perlakuan diberi pakan tanpa tepung ampas kunyit dan kelompok P1: diberi pakan tambahan tepung ampas kunyit 1,07\%. Variabel yang diamati adalah bobot telur (gram), haugh unit, indeks kuning telur, indeks putih telur dan warna kuning telur. Hasil: Rata-rata tertinggi bobot telur, haugh unit, indeks kuning telur dan warna kuning telur berasal dari telur puyuh yang diberi pakan tambahan tepung ampas kunyit 1,07\%, dan rata-rata Indeks Putih Telur dari kedua perlakuan mendapatkan hasil yang sama. Kesimpulan: Pemberian tepung ampas kunyit berpotensi meningkatkan Bobot Telur, Haugh Unit, Indeks Kuning Telur dan Warna Kuning Telur, namun tidak berpotensi meningkatkan Indeks Putih Telur dikarenakan pemberian tepung ampas kunyit tidak berpengaruh secara langsung dalam proses pembentukan putih telur.

\section{ARTICLE INFO}

Recieved: December 16, 2019 Accepted: March 10, 2020

Online: April 30, 2020

${ }^{*}$ Correspondence:

Astrid Annisya Adhy Putri

E-mail:

astridputri326@gmail.com

Keywords:

Quail; Egg Quality; Turmeric

Kata kunci:

Puyuh Petelur; Kualitas

Telur; Kunyit 


\section{PENDAHULUAN}

Puyuh (Coturnix coturnix japonica) merupakan salah satu unggas yang memiliki ukuran tubuh kecil namun mampu memproduksi telur hingga 250-300 butir per ekor per tahun. Populasi puyuh di Indonesia pada tahun 2014 sebanyak 12.692.213 ekor, tahun 2015 sebanyak 13.781.918 ekor dan tahun 2016 mencapai 14.107.687 ekor (Pertanian, 2017).

Telur burung puyuh terdiri atas kuning telur (30\%-33\%), putih telur (52\%-60\%) dan kerabang telur (7\%-9\%) dari berat utuh (Yuwanta, 2010). Telur puyuh segar memiliki kandungan protein sebanyak $13,6 \%$, lemak 8,24\%, karbohidrat 1,0\%, abu 1,1\% dan kadar air 73,7\% (Muchtadi dkk., 2010). Kualitas telur dapat didefinisikan sebagai penampakan dan karakter fisik telur yang mempengaruhi penerimaan oleh pembeli produk tersebut (Sudaryani, 2006). Kualitas telur didapat dengan cara melakukan pengukuran terhadap indeks kuning telur, indeks putih telur dan Haugh Unit (Fibrianti dkk., 2010). Penurunan kualitas telur antara lain disebabkan karena masuknya mikroba perusak ke dalam telur melalui pori kerabang telur, menguapnya air dan gas karena pengaru suhu lingkungan (Haryono, 2000).

Kunyit adalah bahasa umum untuk Indonesia, walaupun di setiap daerah ada perbedaan nama. Di India, kunyit disebut kurkuma atau turmerik, merupakan tanaman herbal yang mengandung antibiotik alami dan tidak mengakibatkan residu atau bahaya bila dikonsumsi oleh ternak ataupun manusia (Amo dkk., 2013). Kandungan zat aktif yang terdapat dalam kunyit adalah kurkuminoid dan minyak atsiri. Kurkuminoid merupakan zat pemberi warna kuning pada kunyit. Kurkuminoid berfungsi sebagai penambah nafsu makan yang pada akhirnya akan meningkatkan bobot unggas (Balittro, 2008). Kurkuminoid dapat memberikan zat warna kuning alami terhadap kuning telur sehingga berpotensi meningkatkan nilai warna kuning telur (Amo dkk., 2013). Kandungan minyak atsiri dalam kunyit berfungsi sebagai zat atau obat yang digunakan sebagai peluruh atau penghancur empedu (kalagoga), dalam hal ini dapat meningkatkan sekresi cairan empedu (Atmajaya, 2014). Oleh karena itu, dilakukanlah penelitian untuk mengetahui pengaruh pemberian tepung kunyit terhadap kualitas telur burung puyuh.

\section{MATERIAL DAN METODE}

Pelaksanaan penelitian ini dilakukan di peternakan Bapak Hafizhul Qori yang terletak di Desa Gading Kecamatan Selopuro Kabupaten Blitar. Waktu pelaksanaan dimulai tanggal 14 Februari
2019 sampai dengan 15 Maret 2019. Penelitian ini menggunakan puyuh petelur berumur 56 hari sebanyak 40 ekor. Dua puluh ekor puyuh diberi pakan tanpa kunyit (PO) dan dua puluh ekor puyuh diberi pakan dengan tambahan kunyit 1,07\% (P1), setelah pengamatan catatan produksi puyuh petelur dari tiap perlakuan kemudian dilakukan uji kualitas telur dengan mengambil sampel telur puyuh produksi hari ke-30 sebanyak 10 butir dari tiap perlakuan.

\section{HASIL}

Berdasarkan Tabel 1, hasil yang didapat menunjukkan bahwa rata-rata tertinggi bobot telur berasal dari telur dengan ransum yang diberi kunyit yaitu 10,31 gram. Sedangkan rata-rata bobot telur dengan ransum tanpa kunyit adalah 9,5 gram. Hasil yang tidak berbeda jauh dengan penelitian Amo dkk. Hal ini menunjukkan bahwa pemberian tepung ampas kunyit tidak memberikan efek negatif pada bobot telur puyuh, namun berpotensi meningkatkan bobot telur puyuh. Peningkatan bobot telur dipengaruhi oleh banyaknya kandungan protein yang terkandung dalam ransum dan sebagian dari kunyit.

Berdasarkan hasil rata-rata nilai Haugh Unit pada Tabel 2. menunjukkan bahwa nilai Haugh Unit yang didapat termasuk dalam kualitas sangat baik, seperti yang telah dinyatakan oleh Parizadian et al. (2011) bahwa nilai Haugh Unit puyuh segar bisa mencapai 92,88 , dan berdasarkan hasil diatas terlihat bahwa ratarata tertinggi berasal dari telur dengan ransum yang diberi tepung ampas kunyit yaitu 90,52. Perbedaan rata-rata dari kedua perlakuan sebesar 0,54.

Rata-rata nilai indeks kuning telur dapat dilihat pada Tabel 3. Berdasarkan hasil pengamatan didapatkan nilai tertinggi berasal dari telur dengan ransum yang diberi kunyit yaitu 0,43. Hasil yang didapat sesuai dengan standar nilai Indeks Kuning Telur yang dinyatakan oleh Badan Standardisasi Nasional (2008) yaitu berkisar antara 0,33-0,52, yang berarti kualitas telur puyuh termasuk baik. Hasil yang didapat juga sesuai dengan penelitian Kusumastuti dkk. (2012). Hal ini menunjukkan bahwa tepung ampas kunyit berpotensi meningkatkan nilai IKT, namun telur akan mengalami perubahan kualitas seiring dengan lamanya penyimpanan. Semakin lama waktu penyimpanan akan mengakibatkan terjadinya penguapan cairan di dalam telur dan menyebabkan kantung udara semakin besar.

Data rata-rata nilai indeks putih telur dapat dilihat pada Tabel 4. Hasil pengamatan menunjukkan bahwa rata-rata indeks putih telur dari kedua perlakuan sama, yaitu 0,096. Menurut Badan Standardisasi Nasional (2008) nilai indeks putih telur segar berkisar antara

Tabel 1. Rata-rata bobot telur.

\begin{tabular}{lccccccccccc}
\hline \multirow{2}{*}{ Jenis Telur } & \multicolumn{10}{c}{ Bobot Telur } & \multicolumn{10}{c}{ Rata-Rata } \\
\cline { 2 - 13 } & $\mathbf{1}$ & $\mathbf{2}$ & $\mathbf{3}$ & $\mathbf{4}$ & $\mathbf{5}$ & $\mathbf{6}$ & $\mathbf{7}$ & $\mathbf{8}$ & $\mathbf{9}$ & $\mathbf{1 0}$ & \\
\hline Tanpa Kunyit & 10,8 & 8,2 & 9,2 & 9,2 & 11 & 9,7 & 10,2 & 8,3 & 8,4 & 10 & 9,5 \\
\hline Kunyit (1,07\%) & 11,6 & 9,8 & 8,4 & 8,6 & 11 & 11,8 & 10,6 & 10,6 & 9,5 & 11,2 & 10,31 \\
\hline
\end{tabular}


Tabel 2. Rata-rata nilai Haugh unit.

\begin{tabular}{|c|c|c|c|c|c|c|c|c|c|c|c|}
\hline \multirow{2}{*}{ Jenis Telur } & \multicolumn{10}{|c|}{ Haugh Unit } & \multirow{2}{*}{$\begin{array}{l}\text { Rata- } \\
\text { Rata }\end{array}$} \\
\hline & 1 & 2 & 3 & 4 & 5 & 6 & 7 & 8 & 9 & 10 & \\
\hline $\begin{array}{l}\text { Tanpa } \\
\text { Kunyit }\end{array}$ & 87,44 & 91,41 & 84,91 & 97,89 & 91,17 & 97,58 & 82,31 & 92,48 & 92,08 & 82,57 & 89,98 \\
\hline $\begin{array}{l}\text { Kunyit } \\
(1,07 \%)\end{array}$ & 90,74 & 97,83 & 92,60 & 94,20 & 91,17 & 91,45 & 76,32 & 83,49 & 90,95 & 96,44 & 90,52 \\
\hline
\end{tabular}

Tabel 3. Rata-rata nilai indeks kuning telur.

\begin{tabular}{|c|c|c|c|c|c|c|c|c|c|c|c|}
\hline \multirow{2}{*}{ Jenis Telur } & \multicolumn{10}{|c|}{ Indeks Kuning Telur } & \multirow{2}{*}{ Rata-Rata } \\
\hline & 1 & 2 & 3 & 4 & 5 & 6 & 7 & 8 & 9 & 10 & \\
\hline Tanpa Kunyit & 0,46 & 0,43 & 0,40 & 0,47 & 0,41 & 0,46 & 0,34 & 0,43 & 0,47 & 0,36 & 0,42 \\
\hline Kunyit (1,07\%) & 0,36 & 0,44 & 0,43 & 0,39 & 0,50 & 0,47 & 0,48 & 0,41 & 0,45 & 0,42 & 0,43 \\
\hline
\end{tabular}

Tabel 4. Rata-rata nilai indeks putih telur.

\begin{tabular}{lccccccccccc}
\hline & \multicolumn{1}{c}{ Indeks Putih Telur } & Rata-Rata \\
\cline { 2 - 11 } & $\mathbf{1}$ & $\mathbf{2}$ & $\mathbf{3}$ & $\mathbf{4}$ & $\mathbf{5}$ & $\mathbf{6}$ & $\mathbf{7}$ & $\mathbf{8}$ & $\mathbf{9}$ & $\mathbf{1 0}$ & 10 \\
\hline Tanpa Kunyit & 0,076 & 0,103 & 0,070 & 0,131 & 0,096 & 0,126 & 0,071 & 0,108 & 0,107 & 0,073 & 0,096 \\
\hline $\begin{array}{l}\text { Kunyit } \\
(1,07 \%)\end{array}$ & 0,084 & 0,131 & 0,108 & 0,113 & 0,096 & 0,093 & 0,049 & 0,065 & 0,101 & 0,119 & 0,096 \\
\hline
\end{tabular}

Tabel 5. Rata-rata warna kuning telur.

\begin{tabular}{|c|c|c|c|c|c|c|c|c|c|c|c|}
\hline \multirow{2}{*}{ Jenis Telur } & \multicolumn{10}{|c|}{ Warna Kuning Telur } & \multirow{2}{*}{ Rata-Rata } \\
\hline & 1 & 2 & 3 & 4 & 5 & 6 & 7 & 8 & 9 & 10 & \\
\hline Tanpa Kunyit & 6 & 5 & 5 & 5 & 6 & 6 & 5 & 6 & 5 & 5 & 5,4 \\
\hline Kunyit $(1,07 \%)$ & 7 & 7 & 6 & 6 & 6 & 7 & 6 & 7 & 7 & 6 & 6,5 \\
\hline
\end{tabular}

0,050-0,174, yang berarti nilai indeks putih telur yang didapat tergolong berkualitas baik.

Hasil pengamatan untuk warna kuning telur dapat dilihat pada Tabel 5. Berdasarkan tabel diatas dapat dilihat bahwa rata-rata tertinggi berasal dari telur dengan ransum yang diberi tepung ampas kunyit yaitu 6,5. Hal ini sesuai dengan pernyataan Amrullah (2003) jika warna kuning telur mencapai skor 7-8 maka telur akan digolongkan ke dalam kualitas baik. Hal ini menunjukkan bahwa pemberian tepung ampas kunyit tidak memberikan efek negatif terhadap warna kuning telur, melainkan dapat memberikan warna (pigmen) kuning yang baik pada kuning telur sehingga menarik perhatian konsumen pada saat mengkonsumsi telur.

\section{PEMBAHASAN}

Kandungan nutrisi dalam ransum sangat berpengaruh terhadap peningkatan kualitas telur puyuh, salah satunya adalah bobot telur. Pemberian tepung ampas kunyit secara nyata dapat meningkatkan bobot telur dikarenakan kandungan nutrisi yang terdapat dalam ransum yang menggunakan tepung ampas kunyit lebih baik dibandingkan dengan ransum yang tidak menggunakan tepung ampas kunyit. Hal ini berarti menunjukkan bahwa kunyit mempengaruhi secara nyata terhadap kandungan protein, karena dalam kunyit mengandung senyawa aktif yang tergolong antioksidan yang mampu mengatasi/mengurangi stress oksidatif (Kumar and Sharnya, 2006). Kandungan protein dalam kunyit juga membantu meningkatkan ukuran dan bobot dari kuning telur. Selain itu, zat aktif curcuma yang ada pada kunyit memiliki gugus hidroksil yang mudah teroksidasi, sehingga akan mudah pula mendonorkan gugus hidrogen dan elektron kepada radikal bebas, akibatnya muncul radikal bebas yang mengganggu sintesis protein akan dikurangi/ ditekan (Priyadarsini et al., 2003).

Pemberian tepung kunyit kemungkinan tidak secara langsung berpengaruh dalam proses pembentukan putih telur sehingga tidak mempengaruhi nilai Haugh Unit (Kusumastuti dkk., 2012), namun terdapat peningkatan pada bobot telur puyuh yang menggunakan ransum dengan kunyit sehingga dapat membantu meningkatkan nilai Haugh Unit. Faktor yang dapat mempengaruhi nilai Haugh 
Unit adalah bobot telur, tinggi putih telur, suhu dan umur penyimpanan telur.

Faktor yang dapat mempengaruhi nilai indeks putih telur diantaranya tinggi putih telur, diameter putih telur, suhu, kelembaban, porositas kerabang telur dan lama penyimpanan. Pemberian tepung kunyit kemungkinan tidak secara langsung berpengaruh dalam proses pembentukan putih telur (Kusumastuti dkk., 2012) sehingga tidak mempengaruhi nilai indeks putih telur namun juga tidak berpengaruh jelek terhadap nilai indeks putih telur.

Perubahan pada putih telur disebabkan oleh adanya pertukaran gas antara udara luar dengan isi telur melalui pori-pori kerabang telur dan penguapan air (Yuwanta, 2010). Selama penyimpanan, tinggi putih telur kental akan menurun secara cepat, kemudian secara lambat. Penurunan indeks putih telur sangat dipengaruhi oleh suhu penyimpanan, semakin rendah suhu penyimpanan maka semakin kecil penurunannya (Swacita and Cipta, 2011). Adanya penurunan indeks putih telur disebabkan karena hilangnya $\mathrm{CO}$ dan terjadinya pemecahan asam karbonat menjadi $\mathrm{CO}_{2}$, sehingga menyebabkan serat musin kehilangan struktur yang memberikan tekstur kental pada albumen telur dan akhirnya albumen telur menjadi encer (Samli et al., 2005).

Warna kuning telur dapat dipengaruhi oleh pakan. Apabila pakan mengandung lebih banyak karoten, yaitu xanthofil, maka warna kuning telur semakin berwarna jingga kemerahan. (Yamamoto et al., 2007). Warna kuning telur dipengaruhi oleh kandungan kimia dalam kunyit yaitu kurkuminoid yang dapat memberikan zat warna kuning alami terhadap warna kuning telur. Semakin tinggi jumlah level yang diberikan maka semakin meningkat pula warna dari kuning telur (Amo dkk., 2013). Berdasarkan hasil di atas, dapat disimpulkan bahwa pemberian kunyit dalam ransum dapat meningkatkan kualitas warna kuning telur.

\section{KESIMPULAN}

Berdasarkan hasil dan pembahasan yang dijelaskan, dapat disimpulkan bahwa pemberian tepung ampas kunyit dalam ransum berpotensi meningkatkan kualitas telur terutama dalam peningkatan bobot telur, HU, IKT, dan warna kuning telur. Pemberian tepung ampas kunyit tidak berpotensi meningkatkan nilai IPT namun juga tidak memberikan efek negatif, karena pemberian tepung kunyit kemungkinan tidak secara langsung berpengaruh dalam proses pembentukan putih telur. Penurunan indeks kuning telur diduga disebabkan oleh masuknya air dan putih telur kedalam kuning telur, sebagai akibat adanya perbedaan tekanan osmosis antara putih telur dan kuning telur, sehingga kuning telur menjadi encer. Faktor yang dapat mempengaruhi nilai IKT diantaranya tinggi kuning telur, diameter kuning telur, suhu ruangan dan lama penyimpanan.

\section{UCAPAN TERIMA KASIH}

Pada kesempatan ini penulis ingin menyampaikan terima kasih kepada Bapak Hafizhul Qori selaku pemilik peternakan puyuh petelur dan keluarga yang telah membantu untuk melengkapi data dalam keperluan Tugas Akhir dan fasilitas yang diberikan kepada penulis. Penulis menyatakan tidak ada konflik kepentingan dengan pihak-pihak yang terlibat dalam penelitian ini.

\section{DAFTAR PUSTAKA}

Amo, M., Saerang, J. L. P., Najoan, M., Keintjem, J. 2013. Pengaruh Penambahan Tepung Kunyit (Curcuma domestica val) Dalam Ransum Terhadap Kualitas Telur Puyuh (Coturnix coturnix japonica). Jurnal Zootek 33 (1): Pp. 48-57.

Amrullah, I. K., 2003. Nutrisi Ayam Petelur. Bogor: Lembaga Satu Gunung Budi.

Atmajaya, D. A., 2014. Pengaruh Ekstrak Kunyit (Curcuma domestica val) dan Temulawak (Curcuma xanthorriza roxb) dalam air minum terhadap persentase dan kualitas organoleptik karkas ayam broiler. [Skripsi]. Universitas Brawijaya.

Badan Standardisasi Nasional, 2008. Telur Ayam Konsumsi. SNI 01-3926-2008. Jakarta: BSN.

Balittro, 2008. Budidaya Tanaman Kunyit. [Online] Available at: http://www.balittro.go.id/ incles/ kunyit.pdf. Diakses: 25 Maret 2019.

Fibrianti, S. M., Suada, I. K., Rusyanto, M.D. 2012. Kualitas Telur Ayam Konsumsi yang Dibersihkan dan Tanpa Dibersihkan Selama Peyimpanan Suhu Kamar. Indonesia Medicus Veterinus, 1 (3) : Pp. 408-416.

Haryono, 2000. Langkah-Langkah Teknis Uji Kualitas Telur Konsumsi Ayam Ras. Temu Teknis Fungsional non Peneliti. Hal. 175-183.

Kumar V., S.K. Sharnya. 2006. Antioxidant Studies on Some Plants. Hamda Medicus Xlix, (4): Pp. 2536.

Kusumastuti, D. T., Praseno, K., Saraswati, T. R. 2012. Indeks Kuning Telur dan Nilai Haugh Unit Telur Puyuh (Coturnix coturnix japonica) Setelah Pemberian Tepung Kunyit (Cucuma longa). Jurnal Biologi 1 (1): Pp. 5-22.

Muchtadi, T. R., Ayustaningwarno, F., Sugiyono. 2010. Ilmu Pengetahuan Bahan Pangan. Bandung: Penerbit Alfabeta.

Parizadian, B., Ahangari, Y.J., Shargh, M.S., Sardarzadeh A. 2011. Effects of Different Levels of L-carnitine Supplementation on Egg Quality and Blood Parameters of Laying Japanese Quail. Int.J.Poultry Sci. 10 (8): Pp. 621-625.

Pertanian, D. J. P. d. K. H. K., 2017. Statistik Peternakan dan Kesehatan Hewan (Livestock and Animal Health Statistic). s.l.: Direktorat Jenderal Peternakan dan Kesehatan Hewan Kementrian Pertanian RI.

Priyadarsini, K.I., Maity, D.K., Naik, G.H., Kumar, M.S., Unnikrishnan, M.K., Satav, J.K., Mohan, H. 2003. Role of Phoenic O-H and Methylene 
hydrogen on The Free Radical Reactions and Antioxidant Activity of Curcumin. Free RadicalBiol. Med, 35 (5): Pp. 475-484.

Samli, H. E., Agna, A., Senkoylu, N. 2005. Effects of Storage Time and Temperature on Egg Quality in Old Laying Hens. J. Appl. Poult. Res, 14 (3): Pp.548-553.

Sudaryani, T., 2006. Kualitas Telur. Jakarta: Penebar Swadaya.
Swacita, N. I. B., Cipta., I.P.S. 2011. Pengaruh Sistem Peternakan dan Lama Penyimpanan Terhadap Kualitas Telur Itik. Buletin Veteriner Udayana, 3 (2): Pp. 91-98.

Yamamoto, T., L. R., Juneja, Hatta, H., Kim, M. 2007. Hen Eggs : Basic and Appliad Science. Canada: University of Alberta.

Yuwanta, T. 2010 . Telur dan Kualitas Telur. Yogyakarta: Gadjah Mada University Press. 